\title{
Marine depth use of sea trout Salmo trutta in fjord areas of central Norway marine depth use of salmo trutta
}

Eldøy, S. H.; Davidsen, J. G.; Thorstad, E. B.; Whoriskey, F. G.; Aarestrup, Kim; Naesje, T. F.; Rønning, L.; Sjursen, A. D.; Rikardsen, A. H.; Arnekleiv, J. V.

Published in:

Journal of Fish Biology

Link to article, DOI:

$10.1111 / \mathrm{jfb} .13463$

Publication date:

2017

Document Version

Peer reviewed version

Link back to DTU Orbit

Citation (APA):

Eldøy, S. H., Davidsen, J. G., Thorstad, E. B., Whoriskey, F. G., Aarestrup, K., Naesje, T. F., Rønning, L., Sjursen, A. D., Rikardsen, A. H., \& Arnekleiv, J. V. (2017). Marine depth use of sea trout Salmo trutta in fjord areas of central Norway: marine depth use of salmo trutta . Journal of Fish Biology, 91(5), 1268-1283. https://doi.org/10.1111/jfb.13463

\section{General rights}

Copyright and moral rights for the publications made accessible in the public portal are retained by the authors and/or other copyright owners and it is a condition of accessing publications that users recognise and abide by the legal requirements associated with these rights.

- Users may download and print one copy of any publication from the public portal for the purpose of private study or research.

- You may not further distribute the material or use it for any profit-making activity or commercial gain

- You may freely distribute the URL identifying the publication in the public portal 
Received 23 February 2017

Accepted 26 July 2017

\section{Marine depth use of sea trout Salmo trutta in fjord areas of}

\section{Central Norway}

S. H. ELDØY, J. G. DAVIDSEN, E. B. THORSTAD, F. G. WHORISKEY, K.

AARESTRUP, T. F. NÆSJE, L. RØNNING, A. D. SJURSEN, A. H. RIKARDSEN AND J.

V. ARNEKLEIV

S. H. Eldøy (sindre.eldoy@ ntnu.no), J. G. Davidsen (jan.davidsen@ ntnu.no) L. Rønning (lars.ronning@ntnu.no), A. D. Sjursen (aslak.sjursen@ntnu.no) and J. V. Arnekleiv

(jo.arnekleiv@ntnu.no). NTNU University Museum, Norwegian University of Science and Technology, NO-7491 Trondheim, Norway.

E. B. Thorstad (eva.thorstad@nina.no) and T. F. Næsje (tor.naesje@nina.no). Norwegian Institute for Nature Research, NO-7485 Trondheim, Norway.

F. G. Whoriskey (fwhoriskey@ dal.ca). Ocean Tracking Network, Dalhousie University, Halifax, NS B3H 4J1, Canada.

K. Aarestrup (kaa@ aqua.dtu.dk). Technical University of Denmark, National Institute of Aquatic Resources, DK-8600 Silkeborg, Denmark. 
A. H. Rikardsen (audun.rikardsen@ uit.no). The Arctic University of Norway, NO-9037 Troms $\varnothing$, Norway.

Running headline: Marine depth use of Salmo trutta

Corresponding author: Jan Grimsrud Davidsen, NTNU University Museum, Norwegian University of Science and Technology, NO-7491 Trondheim; Norway. Tel.: +47924 64314; email: jan.davidsen@ntnu.no.

Key words: acoustic telemetry; brown trout; marine migration; migratory behaviour; swimming depth 


\section{ABSTRACT}

The vertical behaviour of 44 veteran sea trout Salmo trutta $(275-580 \mathrm{~mm})$ in different marine fjord habitats (estuary, pelagic, near shore with and without steep cliffs) was documented during May to February by using acoustic telemetry. The swimming depth of S. trutta was influenced by habitat, time of day (day $v s$ night), season, seawater temperature and the body length at the time of tagging. Mean swimming depth during May - September was $1.7 \mathrm{~m}$ (individual means ranged from 0.4-6.4 m). Hence, the sea trout were generally surface oriented, but performed dives down to $24 \mathrm{~m}$. Mean swimming depth in May - September was deeper in the near shore habitats with or without steep cliffs ( $2.0 \mathrm{~m}$ and $2.5 \mathrm{~m}$ respectively) than in the pelagic areas $(1.2 \mathrm{~m})$. May-September mean swimming depth in all habitats was slightly deeper during day $(1.9 \mathrm{~m})$ than at night $(1.2 \mathrm{~m})$, confirming that $S$. trutta conducted small-scale diel vertical movements. During summer, S. trutta residing in near shore habitat progressively moved deeper over the period May (mean $1.1 \mathrm{~m}$ ) to August (mean $4.0 \mathrm{~m}$ ), and then reoccupied shallower areas $($ mean $=2.3 \mathrm{~m}$ ) during September. In winter (November and February), individuals residing in the innermost part of the fjords were found at similar average depths as they occupied during the summer (mean $=1.3 \mathrm{~m})$. The swimming depths of sea trout coincide with the previously known surface orientation of salmon lice Lepeophtheirus salmonis. Combined with previous studies on horizontal use of sea trout, this study illustrates how sea trout utilize marine water bodies commonly influenced by anthropogenic factors such as aquaculture, harbours and marine constructions, marine renewable energy production or other human activity. This suggests that the marine behaviour of sea trout and its susceptibility to coastal anthropogenic factors should be considered in marine planning processes. 


\section{INTRODUCTION}

In rivers with a two-way connectivity for fish to the sea, brown trout Salmo trutta (Linnaeus 1758) populations often consist of both river-resident and anadromous individuals (Klemetsen et al., 2003). Anadromous $S$. trutta perform marine migrations in order to maximize their feeding opportunities, and ultimately enhance their fitness (Jonsson \& Jonsson, 1993). Although the better at-sea feeding opportunities can improve individual fitness, there are also stressors and risks associated with migration, including higher energy expenditures for locomotion and osmoregulation, increased predation risk, and exposure to novel pathogens (Thorstad et al., 2016).

Marine survival and behaviour of salmonids are highly variable spatially and temporally, with some of the most influential factors being temperature, physiological state, and fish size (Drenner et al., 2012). Salmo trutta is among the lesser studied salmonids in the marine environment (Drenner et al., 2012) and our present knowledge of the marine distribution and behaviour of the species is incomplete, limiting our ability to assess potential threats and implement appropriate conservation measures for this valued species.

In Norway, potential marine stressors and threats for $S$. trutta, such as salmon lice Lepeophtheirus salmonis (Krøyer 1837) infections associated with salmon farming activity (Thorstad et al., 2015), may not only vary in time and among sites, but also with depth (Heuch et al., 1995). However, our knowledge of the use of the water column by S. trutta in the marine environment is limited (e.g. Rikardsen et al., 2007; Gjelland et al., 2014; Aarestrup et al., 2015). Further knowledge of the species' marine migration, habitats occupied, and depth use will help in implementing appropriate conservation measures.

The aim of this study was to use acoustic telemetry to examine spatial and temporal variation in marine depths occupied by free-ranging wild S. trutta in the Hemnfjord/Snillfjord 
system in Norway. At this site the horizontal movements and selected marine behaviour of the S. trutta individuals included in this study were previously analysed (Eldøy et al. 2015).

Marine residence time and area use varied among $S$. trutta individuals, and marine behaviour was influenced by individual morphology and life history characteristics (Eldøy et al., 2015). However, the previous analysis did not consider use of the water column by the sea trout. Lack of previous knowledge about $S$. trutta habitat occupancy at sea made accurate predictions difficult, and simple null-hypotheses (no effect) were used as background for the different habitat occupancy comparisons (estuary, pelagic, near shore with and without steep cliffs), time of day comparisons (day $v s$ night) and inter seasons comparison (month during summer, summer $v s$ winter) in the present study. Furthermore, we tested the null-hypothesis that the variance in individual daily swimming depth did not vary among habitats during day or night.

\section{MATERIALS AND METHODS}

\section{STUDY AREA}

The study was performed in a fjord system in Sør-Trøndelag County, Central Norway. The fjord's inner part is divided in two interconnected fjord arms, the Hemnfjord and Snillfjord. Together, the two inner fjords cover more than $60 \mathrm{~km}^{2}$ of sea surface and have $65 \mathrm{~km}$ of shoreline (Fig. 1). The fjord system is connected to the open sea through a $36 \mathrm{~km}$ long strait. Water column depths in the study area ranged from about 0-100 $\mathrm{m}$ in the near shore areas, to a maximum of about $400 \mathrm{~m}$ in the deepest parts. The study was conducted from 22 April -4 December 2013, and 4 February - 1 March 2014. Summer was defined as the period from May to the end of September, and winter as November to the end of February (but see below for small site-specific variations in these definitions). The other months of the study were considered transitional periods between seasons. 
There were two active salmon farms within the fjord system during the study (Fig. 1). Weekly salmon lice counting conducted by the farmers showed average lice values ranging from 0 to 1.25 salmon lice in motile stages, and from 0 to 0.3 adult female salmon lice per salmon in the salmon pens within the study period.

\section{ENVIRONMENTAL VARIABLES}

Three temperature and salinity recorders (DST milli-CT, www.star-oddi.com, recordings stored every tenth minute) were deployed at $1 \mathrm{~m}$ depth in the fjord system: the first $1 \mathrm{~km}$ from the mouth of the River Søa in the Hemnfjord (array H1), the second $600 \mathrm{~m}$ from the mouth of the River Snilldalselva in the Snillfjord, and the third at the middle receiver of the outermost receiver array (array H3, Fig. 1). Profiles of conductivity and temperature were recorded from 0-15 $\mathrm{m}$ in the central part of Hemnfjord on 1 May and 15 August 2013 using an SD204 CTD (www.saivas.no).

\section{FISH CAPTURE AND TAGGING}

In total, 44 S. trutta that had previously undertaken marine migrations (e.g., were veteran migrants, of which some were previous spawners and some had not spawned before) were tagged with individually coded acoustic transmitters equipped with depth sensors (Thelmabiotel AS, model ADT-9-long, 9 x 39 mm, mass in air $6.8 \mathrm{~g}$, tag duration of minimum 267 days, depth resolution $10 \mathrm{~cm}$, max depth $100 \mathrm{~m}$, power output $146 \mathrm{~dB}$ re $1 \mathrm{uPa}$ at $1 \mathrm{~m}$, nominal delay $30-90 \mathrm{sec}$ ). The fish came from two watercourses draining into the fjord. At the mouth of River Snilldalselva, 15 S. trutta (natural length, $L_{N}$ : mean $=381, \mathrm{SD}=53$, range $275-460 \mathrm{~mm}$ ) were captured using constantly monitored gillnets (35 - $42 \mathrm{~mm}$ mesh width), and tagged during $22-23$ April 2013. An additional 29 S. trutta $\left(L_{N}\right.$ : mean $=417$, SD $=55$, range $330-580 \mathrm{~mm}$ ) were captured using gillnets and tagged at the mouth of River Søa 
during 3 - 12 May 2013. The tagged fish had a mean body condition factor of 0.95 (SD = 0.13 , range $0.75-1.33$ ). Based on scale growth ring deposition patterns, the fish had a mean length at smoltification (back-calculated length assuming linear relationship between body length and scale growth, Závorka et al., 2014) of $143 \mathrm{~mm}(\mathrm{SD}=39$, range 96-246 mm), a mean smolt age of 2.4 years ( $\mathrm{SD}=0.6$, range 2.0-4.0 years), had undertaken a mean of 3.1 previous marine migrations $(\mathrm{SD}=0.9$, range $2.0-6.0)$ and had a mean age of 5.6 years $(\mathrm{SD}=$ 1.0, range 4.0-8.0) at the time of tagging. The tags were surgically inserted through a 1.5-2.0 $\mathrm{cm}$ incision into the body cavity of fish anesthetized with 2-phenoxyethanol (EC No. 204589-7; SIGMA Chemical Co., USA; $0.5 \mathrm{ml} \cdot \mathrm{L}^{-1}$ water). The recovered $S$. trutta were released close to their capture site (see Eldøy et al. 2015).

\section{TRACKING OF TAGGED FISH}

The tagged fish were tracked using 39 acoustic receivers moored $5 \mathrm{~m}$ below the sea surface (Fig. 1; Vemco Inc. model VR2W). The receivers were operative from 22 April to 1 December 2013 and again from 6 February 2014 to 1 March 2014. The distance between receivers in the receiver arrays ranged between 332 and $660 \mathrm{~m}$ (Array H1, H2, H3 and S1, Fig. 1). The receivers were not operational during December - January due to logistical constraints. Tag detection range was tested at the central receiver of array H1 (Fig. 1) on 22 August 2013 (calm, clear weather, high tide) by deploying acoustic transmitters similar to those used in the study at 3 and $5 \mathrm{~m}$ depth, and at increasing distance to the receiver in steps of $50 \mathrm{~m}$. Maximum detection range was $350 \mathrm{~m}$ at both depths. The detectability at ALS arrays $\mathrm{H} 1$ and $\mathrm{H} 2$ (fig. 1) were further investigated by controlling if any fish had passed the array without being registered. Here, all the individuals were registered at the investigated arrays prior to first registration outside the arrays, indicating that the arrays successfully detected passing fish. 


\section{DATA FILTERING}

Fish depths could only be recorded when a tagged individual was within the range of an acoustic receiver. Before use, the depth sensing acoustic tags were tested at water surface and at $5 \mathrm{~m}$ depth. The results indicated that there were no need for subsequently calibration of the recorded depth data. The 42 fish generated a total of 1,161,998 valid detections during the study. In addition, there was a total of 1,137 registrations containing false transmitter ID's which were discarded. Two fish were never recorded. As 136,821 (12\%) of the registrations were suspected to be from either dead fish or a shed tag (e.g., Thorstad et al. 2013), these registrations were excluded from analyses. A data filter was added to the data from the two receivers in the mouth of the River Søa and the three innermost receivers in Snillfjord, because these receivers contained higher frequencies of false detections, likely due to code collisions when a large number of tagged fish were within the receiver range simultaneously. The data filter required at least two registrations from a tagged individual within a time span of 10 minutes to accept the registrations, which excluded an additional 16,881 (1.5\%) of the registrations from analyses.

\section{DEFINING HABITAT AT RECEIVER LOCATIONS}

The habitat at each receiver (i.e. the area within its range) was categorised as either estuarine, near shore without steep cliffs, near shore with steep cliffs, or pelagic habitat (Fig. 1). Receivers deployed near river mouths in the fjord were highly influenced by the freshwater outflow, and categorized as estuarine habitat. Receivers deployed near $(<200 \mathrm{~m})$ the shore, or in areas with shallow water $(<15 \mathrm{~m}$ depth), were defined as near shore habitat without steep cliffs. Receivers deployed over deep water with steep cliffs, but no shallow areas, along the shoreline were described as near shore habitat with steep cliffs. Finally, receivers deployed 
over deep water, $>600 \mathrm{~m}$ from the shore and without shallow areas $(<15 \mathrm{~m}$ depth) within the receiver range were defined as pelagic habitat.

\section{DATA ANALYSES}

Analyses of swimming depth during summer for fish tagged at the River Snilldalselva covered the period 1 May - 1 October 2013, and for fish tagged at the River Søa from tagging (3-12 May) until 1 October 2013. Analyses of swimming depth during winter covered the periods 1 November - 1 December 2013 and 6 February - 1 March 2014 (acoustic receivers were not deployed during 4 December 2013 - 6 February 2014). To distinguish between summer and winter residence at sea, data from October were not included because some individuals were showing transitional behaviour and only spent a few days at sea, probably due to spawning. Swimming depths were compared among habitats and between day and night. Day time was defined as the time between sunrise and sunset using the calculator of the Astronomical Applications Department of the US Naval Observatory (aa.usno.navy.mil) for the coordinates $63^{\circ} 22^{\prime} 00.0^{\prime \prime} \mathrm{N} 9^{\circ} 13^{\prime} 00.0^{\prime \prime} \mathrm{E}$. Night was defined as the time between sunset and sunrise.

All statistical analyses were conducted using R Studio version 1.0.44 (RStudio Team, 2015). For analysis of factors influencing the swimming depth of sea trout during summer, a mixed effect model was constructed using the "lme" function in the R package lnme (Pinheiro et al., 2017), where fish ID was assigned as a random factor. The initial global model included log-transformed swimming depth as the response variable, habitat, body length, month during summer, water temperature and time of day (day $v s$ night) as fixed effects, as well as fish ID as a random effect. Akaike's information criterion was used to identify the best fitting model using the "dredge" function in the R package MuMIn (Barton, 2013). The function "cor.test" in R was used to evaluate whether body length of the fish correlated with 
the individuals difference in swimming depth between day and night. For analysis of difference in means between two groups, paired $t$-tests were conducted assuming unequal variance between groups. For non-normally distributed data, paired Mann-Whitney U-tests were applied for comparisons of two groups. To test for differences in swimming depth among habitats, Tukey's HSD (R-package Multcomp, Hothorn et al., 2008) tests were conducted on a mixed effects model ("lme" function in the R package lnme, Pinheiro et al., 2017) including log-transformed swimming depth as response variable, habitat as fixed effect and fish ID as random effect. Individual mean values were used to calculate the population mean values in order to keep the data points independent.

The proportions of detections at different depths were compared between the littoral and pelagic habitat during summer. Individual daily movement activity within habitats during day and night, hereafter referred to as "vertical movement activity" (VMA), was investigated by calculating individual standard deviation values from daily mean swimming depth. VMA values generated from less than 10 registrations were excluded from further analyses. To test for significant differences in VMA among habitats and between day and night, Tukey's HSD (R-package Multcomp, Hothorn et al., 2008) were conducted on a mixed effect model ("Ime" function in the $\mathrm{R}$ package lnme, Pinheiro et al., 2017) including daily SD of individual swimming depth as the response variable, Julian day, habitat and time of day (day $v s$ night) as fixed effects and fish ID as a random effect. In order to account for data heterogeneity, a combination of variance structures was added to the model ("varComb" function in the R package lnme, Pinheiro et al., 2017), combining the "varConstPower" for Julian day and the "varIdent" function for habitat. The data and residuals of the models and groups in the statistical tests were visually inspected to check for assumption violations. 


\section{RESULTS}

Mean daily water temperature during summer at $1 \mathrm{~m}$ depth in the outer part of the study area was similar to or slightly lower than that in the inner parts of both Hemnfjord and Snillfjord (Table 1). Water temperatures increased towards the end of July and thereafter declined (Fig. 2). Salinities at $1 \mathrm{~m}$ depth during summer were brackish in both the outer study area and in the inner parts of Hemnfjord, and Snillfjord (Table 1). The water column temperature and salinity in the central Hemnfjord were relatively stable from $0-15 \mathrm{~m}$ depth in both April $\left(5^{\circ} \mathrm{C}\right.$; salinity 33) and August ( $13{ }^{\circ} \mathrm{C}$; salinity 34-37, Fig. 3).

The temperature at $1 \mathrm{~m}$ depth during November was similar in the different fjord areas. The water was less saline in the inner parts of Snillfjord, than the other areas during November (Table 1). The mean water temperature at 1 meter depth in the inner parts of Hemnfjord was $6.9^{\circ} \mathrm{C}$ and was close to full saline seawater during 4 February - 1 March (Table 1). Temperature and salinity were not recorded at the outer site and in Snillfjord in February due to logistical constraints.

The four best mixed effect models all indicated that the swimming depth of S. trutta during summer was influenced by habitat, time of day (day vs night) and month, while the best model (marginal R_GLMM ${ }^{2}=0.37, P<0.001$ ) also included water temperature and fish length as explanatory variables (Table 2, Table 3). Mean swimming depth for all fish in all habitat types during summer was $1.7 \mathrm{~m}(\mathrm{SD}=1.3$, range of individual means $=0.4-6.4)$. The deepest depths recorded for the different individuals varied between $4.6 \mathrm{~m}$ and $24.0 \mathrm{~m}$ (mean of deepest recordings from all individuals $14.1 \mathrm{~m}, \mathrm{SD}=4.9)$. In the near shore habitat without steep cliffs, fish moved progressively deeper from May until August, but thereafter moved closer to the surface again; however, the number of $S$. trutta recorded in the pelagic and the near shore habitat with steep cliffs was low from June to September (Fig. 4). The fish resided 
slightly deeper during day than at night within all types of marine habitats $(P<0.05$, Table 4 , Fig. 5). Fish body length did not correlate with the swimming depth difference between day and night (Pearson's correlation $=0.08, n=40, P=0.64$ ).

The Tukey HSD post hoc test on the mixed effect model of swimming depth revealed that the $S$. trutta had greater swimming depth in both near shore habitat without (mean = 2.0, $\mathrm{SD}=1.5$, range $=0.4-6.7 \mathrm{~m}$,$) and with steep cliffs ($ mean $=2.5, \mathrm{SD}=1.6$, range $=0.3-7.1 \mathrm{~m}$, compared to the estuarine habitat (mean $=0.9, \mathrm{SD}=0.5$, range $=0.4-2.6 \mathrm{~m}, P<0.001$ ). The Tukey HSD post hoc test also showed that fish were recorded deeper in both the near shore habitat without steep cliffs and the near shore habitat with steep cliffs compared to the pelagic habitat $($ mean $=1.2, \mathrm{SD}=1.1$, range $=0.1-4.9 \mathrm{~m}, P<0.001)$. Finally, the Tukey HSD post $h o c$ test revealed that swimming depths of $S$. trutta were greater in the pelagic habitat than in the estuarine habitat $(P<0.001)$, and deeper in the near shore habitat with steep cliffs compared to near shore habitat without steep cliffs $(P<0.001)$.

The depth distribution of individual's registrations varied between habitats (Table 5). Vertical movements were generally larger during day than night (Table $6, \mathrm{P}<0.001$ ). The Tukey HSD post hoc tests on the mixed effect DVM model (Table 3) revealed that the DVM were greater in the near shore habitats compared to the estuarine and pelagic habitats during day $(P<0.01)$. Similary, the Tukey HSD post hoc tests showed that the DVM were greater in the near shore habitat without steeps cliffs compared to the estuarine and pelagic habitat $(P<$ $0.001)$, and greater in the near shore habitat with cliffs compared to the pelagic habitat $(P<$ $0.05)$ during night.

Six individuals were recorded at near-shore or river mouth receivers in the innermost parts of Hemnfjord (two fish) and Snillfjord (four fish) during winter. Despite winter temperatures, the fjord was not ice covered. Mean individual swimming depth was $1.3 \mathrm{~m}$ (SD $=0.5$, range $0.5-1.9$. The deepest depths recorded during winter for these individuals varied 
between $9.7 \mathrm{~m}$ and $34.2 \mathrm{~m}$ (mean of deepest recordings $20.9 \mathrm{~m}, \mathrm{SD}=9.5$ ). The $S$. trutta had greater individual mean swimming depth during day (mean $=2.0 \mathrm{~m}, \mathrm{SD}=0.6 \mathrm{~m}$, range 1.3$2.9 \mathrm{~m})$ than at night $($ mean $=1.0 \mathrm{~m}, \mathrm{SD}=0.5 \mathrm{~m}$, range $0.3-1.7 \mathrm{~m})$ also during the winter period (Pared t-test, $t=6.07$, d.f. $=5, P<0.001)$.

\section{DISCUSSION}

Swimming depths of S. trutta individuals in this study were generally surface oriented, but influenced by habitat (estuary, pelagic, near shore with or without steep cliffs), time of day (day $v s$ night), month of summer, water temperature and fish size. Salmo trutta had deeper swimming depths in near shore areas compared to pelagic areas. The swimming depth in estuaries was shallower than in other habitats, possibly influenced by the shallow nature of these areas. The fish we followed in winter showed similar depth-use patterns in the winter as during the summer - but it should be noted that the number of tagged individuals detected at sea during winter was low. The surface-orientation of $S$. trutta in this study is similar to that observed for electronically tagged, free-ranging wild sea trout in previous studies. Rikardsen et al. (2007) found that $S$. trutta stayed close to the surface in the Alta fjord in northern Norway, recording a mean swimming depth of 1.8 meters (eight $S$. trutta tagged with data storage tags). Gjelland et al. (2014) observed that $S$. trutta infested with salmon lice ( $L$. salmonis) were mainly recorded between 1 and 3 meter depth in the Etnefjord, south-western Norway. The present study confirms that this surface orientation is exhibited by the species across a range of different marine habitat types, and remains consistent across seasons.

S. trutta are vulnerable to being infested with salmon lice because of their surfaceoriented behaviour, which overlaps with the distribution of salmon lice larvae (Heuch et al., 1995; á Norði et al., 2016). On the other hand, in coastal areas with a surface freshwater layer due to high influx of freshwater from rivers, sea trout may be protected against salmon lice 
due to their surface orientation, because salmon lice do not cope well with freshwater and brackish water (Wootten et al., 1982; Johnson \& Albright, 1991; Bricknell et al., 2006). The local salmon farmers reported varying salmon lice concentrations in the pens during the study period, indicating that the $S$. trutta individuals probably experienced variable lice infection pressure depending on their spatial and temporal use of the marine habitat. Salmon lice infestation has earlier been found to alter the marine behaviour of sea trout regarding timing of return to estuaries and rivers (e.g. Birkeland, 1996; Bjørn et al., 2001; Gjelland et al., 2014). Furthermore, Bui et al. (2016) found that farmed Atlantic salmon (S. salar) in salmon pens altered their swimming depth in response to high infestation rates of salmon lice. However, it remains unknown whether the depth distributions of the $S$. trutta individuals observed in the current study were in whole or in part a response to salmon lice infestation, as their actual infection rates could not be documented.

Despite the statistical significance of the diel movements of $S$. trutta observed in this study, the biological significance of these movements is unclear since the difference in swimming depth between day and night was not large (one meter or less). The small difference in depth use between day and night could be explained by the minor differences in light between day and night during mid-summer due to the bright summer nights at the latitude of the study area. However, the small-scale difference in depth use between day and night was consistent among seasons, suggesting it is a general pattern rather than resulting from summer light conditions in the study area.

Vertical day-night movements are common in many aquatic taxa (Hays, 2003). The phenomenon is thought to be governed by light (Appenzeller \& Leggett, 1995), and earlier studies have suggested that such migratory behaviour might be triggered by body temperature regulative behaviour, feeding activity and/or anti-predator behaviour (e.g. Clark \& Levy, 1988). Diel vertical movement patterns have previously been recorded by Davidsen et al. 
(2008) for S. salar L. post-smolt, and they suggested that the observed vertical movement was a result of a trade-off between avoiding predation by avian and marine predators, feeding and/or osmoregulatory advantages. This might also be the case for the $S$. trutta in the present study. As the size of the veteran $S$. trutta tagged in the present study was larger than postsmolt of $S$. salar, the tagged individuals in the present study might have shown less antipredator behaviour than the $S$. salar post-smolt in the study by Davidsen et al. (2008). We found no effect of body size on diurnal changes in swimming depth. This may suggest that although large individuals are less prone to predation than smaller ones, predation still has highly undesirable impacts on individual fitness and that antipredator behaviour therefor may be a basic instinct that remains active through all $S$. trutta life stages.

Pemberton et al. (1976) investigated the diel feeding of S. trutta, and found increased intake of mid-water and surface prey and a decrease in benthic prey during night. They suggested that the $S$. trutta were more likely to detect prey that were above the substrate or at the surface at night, and that there could be varying conspicuousness of the littoral prey between day and night. In the present study, an increased variability in depths used during day compared to at night was observed, possibly reflecting episodic benthic feeding activity, at least in the near shore and estuary habitats. Hence, the difference between day and night in the present study might partly be explained by a shift in prey type, and be linked to changes in the detectability of the different prey.

The increased swimming depth from May towards August coincided with an increase in water temperature. Rikardsen et al. (2007) observed similar patterns in the Altafjord in northern Norway, where the S. trutta progressively resided in deeper water as temperatures increased during the month of June. It might be suggested that the S. trutta actively regulated their ambient temperature by seeking water layers of preferred temperatures, as earlier suggested by Rikardsen et al. (2007) and Jensen et al. (2014). Jensen et al. (2014) suggested 
that $S$. trutta actively sought out the warmest areas in the fjord. In contrast, $S$. trutta in the present study tended to reside deeper when the temperature increased, suggesting that they moved into colder water during the warmest periods in summer. The study of Jensen et al. (2014) was performed in the northern portion of the species range in an area with lower sea temperatures, which may explain the species differences between the two sites. The warmest temperatures $\left(16^{\circ} \mathrm{C}\right.$ and $\left.18{ }^{\circ} \mathrm{C}\right)$ recorded at 1 meter depth in this study were in outer part of the study area and in the inner parts of both Hemnfjord and Snillfjord, respectively. Rikardsen et al. (2007) reported that individual mean ambient temperatures for S. trutta in the Alta Fjord in June and July ranged between $12{ }^{\circ} \mathrm{C}$ and $13{ }^{\circ} \mathrm{C}$. Another possible reason for the deeper swimming towards late summer might be a shift in prey type, or that the prey also moved deeper due to changing water temperatures. Stomach analyses of $S$. trutta caught in previous studies showed that polychaetes and marine crustaceans were important early in the season, while fish were more important during late summer (Knutsen et al., 2001; Rikardsen et al., 2006). This may suggest that prey type varies with seasonal changes in the prey availability, and potentially explain the difference in swimming depth over the summer.

In conclusion, we found sea trout were surface-oriented during their marine migration, both during summer and also in winter. Fish body size influenced the depth use of S. trutta during summer. Body size also influenced horizontal movements of the same individuals, showing that individual morphology and life history influenced the marine behaviour of $S$. trutta (Eldøy et al., 2015). Slight differences in depth use among individuals and habitats, between day and night, as well as during the summer season, were observed. These are clearly important to the animals, but the biological significance of these small changes are at present unclear. Water temperature was positively correlated with swimming depth, which might suggest that the sea trout actively adjusted their body temperature by seeking preferred ambient temperatures. Collectively, the present study and Eldøy et al (2015) illustrate that sea 
trout utilize coastal water bodies commonly influenced by anthropogenic factors such as aquaculture, harbours and marine constructions, marine renewable energy production or other human activity. This suggests that the impact from anthropogenic factors may vary both among $S$. trutta populations and among individuals within a population according to their temporal and spatial movements in the marine coastal areas. Behavioural differences among populations is thus important to account for when assessing the impact of human activities in the coastal zone, and when introducing fishing regulations for sea trout and for fisheries where sea trout might be captured as bycatch.

\section{ACKNOWLEDGEMENTS}

The study was financed by the Hemne municipality, the County Governor of Sør-Trøndelag, Sør-Trøndelag County Authority, the Norwegian Environment Agency, the Lake Rovatnet landowners association, Trønder Energi AS, Aqua Gen AS, Dalhousie University (Ocean Tracking Network), Norwegian Institute for Nature Research, DTU Aqua, Uit the Arctic University of Norway, and NTNU University Museum. The crew of RV Gunnerus, Martin Georg Hansen, Ola Magne Taftø, Hans Erlandsen, Vegard Pedersen Sollien, Paul Skarsvåg, Stein Hugo Hemmingsen and Kristian Lian, are thanked for extensive help during the field work. Marc Daverdin (NTNU University Museum), Anders Gravbrøt Finstad (NTNU University Museum) and Robert J. Lennox (Carleton University) are thanked for assistance with data analyses. The acoustic receivers were part of the Ocean Tracking Network, www.oceantrackingnetwork.org. The experimental procedures concur with the national ethical requirements and were approved by the Norwegian National Animal Research Authority. Five anonymous reviewers are thanked for commenting on earlier drafts of the manuscript. 


\section{REFERENCES}

á Norði, G., Simonsen, K. \& Patursson, Ø. (2016). A method of estimating in situ salmon louse nauplii production at fish farms. Aquaculture Environment Interactions 8, 397 405.

Aarestrup, K., Baktoft, H., Thorstad, E. B., Svendsen, J. C., Höjesjö, J. \& Koed, A. (2015). Survival and progression rates of sea trout kelts (Salmo trutta L.) during downstream migration in freshwater and at sea. Marine Ecology Progress Series 535, 185-195.

Appenzeller, A. R. \& Leggett, W. C. (1995). An Evaluation of Light-Mediated Vertical Migration of Fish Based on Hydroacoustic Analysis of the Diel Vertical Movements of Rainbow Smelt (Osmerus-Mordax). Canadian Journal of Fisheries and Aquatic Sciences 52, 504-511.

Barton, K. (2013). MuMIn: Multi-model inference. R package version 1.9. 5. R Project for Statistical Computing, Vienna, Austria.

Birkeland, K. (1996). Consequences of premature return by sea trout (Salmo trutta) infested with the salmon louse (Lepeophtheirus salmonis Krøyer): migration, growth, and mortality. Canadian Journal of Fisheries and Aquatic Sciences 53, 2808-2813.

Bjørn, P. A., Finstad, B. \& Kristoffersen, R. (2001). Salmon lice infection of wild sea trout and Arctic char in marine and freshwaters: the effects of salmon farms. Aquaculture Research 32, 947-962.

Bricknell, I., R., Dalesman, S., J., O’Shea, B., Pert, C., C. \& Luntz, A. J. M. (2006). Effect of environmental salinity on sea lice Lepeophtheirus salmonis settlement success. Diseases of Aquatic Organisms 71, 201-212.

Bui, S., Oppedal, F., Stien, L. \& Dempster, T. (2016). Sea lice infestation level alters salmon swimming depth in sea-cages. Aquaculture Environment Interactions 8, 429-435. 
Clark, C. W. \& Levy, D. A. (1988). Diel vertical migrations by juvenile Sockeye salmon and the antipredation window. American Naturalist 131, 271-290.

Davidsen, J. G., Plantalech Manel-la, N., Økland, F., Diserud, O. H., Thorstad, E. B., Finstad, B., Sivertsgård, R., McKinley, R. S. \& Rikardsen, A. H. (2008). Changes in swimming depths of Atlantic salmon Salmo salar post-smolts relative to light intensity. Journal of Fish Biology 73, 1065-1074.

Drenner, S. M., Clark, T. D., Whitney, C. K., Martins, E. G., Cooke, S. J. \& Hinch, S. G. (2012). A synthesis of tagging studies examining the behaviour and survival of anadromous salmonids in marine environments. Plos One 7(3), e31311.

Eldøy, S. H., Davidsen, J. G., Thorstad, E. B., Whoriskey, F., Aarestrup, K., Næsje, T. F., Rønning, L., Sjursen, A. D., Rikardsen, A. H. \& Arnekleiv, J. A. (2015). Marine migration and habitat use of anadromous brown trout Salmo trutta. Canadian Journal of Fisheries and Aquatic Sciences 72, 1366 - 1378.

Gjelland, K. Ø., Serra-Llinares, R. M., Hedger, R. D., Arechavala-Lopez, P., Nilsen, R., Finstad, B., Uglem, I., Skilbrei, O. T. \& Bjørn, P. A. (2014). Effects of salmon lice infection on the behaviour of sea trout in the marine phase. Aquaculture Environment Interactions 5, 221-233.

Hays, G. C. (2003). A review of the adaptive significance and ecosystem consequences of zooplankton diel vertical migrations. Hydrobiologia 503, 163-170.

Heuch, P. A., Parsons, A. \& Boxaspen, K. (1995). Diel vertical migration - a possible hostfinding mechanism in salmon louse (Lepeophtheirus salmonis) copepodids. Canadian Journal of Fisheries and Aquatic Sciences 52, 681-689.

Hothorn, T., Bretz, F. \& Westfall, P. (2008). Simultaneous inference in general parametric models. Biometrical Journal 50, 346-363. 
Jensen, J. L. A., Rikardsen, A. H., Thorstad, E. B., Suhr, A. H., Davidsen, J. G. \& Primicerio, R. (2014). Water temperatures influence the marine area use of Salvelinus alpinus and Salmo trutta. Journal of Fish Biology 84, 1640-1653.

Johnson, S. C. \& Albright, L. J. (1991). Development, Growth, and Survival of Lepeophtheirus Salmonis (Copepoda: Caligidae) Under Laboratory Conditions. Journal of the Marine Biological Association of the United Kingdom 71, 425-436.

Jonsson, B. \& Jonsson, N. (1993). Partial migration: niche shift versus sexual maturation in fishes. Reviews in Fish Biology and Fisheries 3, 348-365.

Klemetsen, A., Amundsen, P.-A., Dempson, J. B., Jonsson, B., Jonsson, N., O`Connell, M. F. \& Mortensen, E. (2003). Atlantic salmon Salmo salar L., brown trout Salmo trutta L., and Arctic charr Salvelinus alpinus (L.): a review of aspects of their life histories. Ecology of Freshwater Fish 12, 1-59.

Knutsen, J. A., Knutsen, H., Gjøsæter, J. \& Jonsson, B. (2001). Food of anadromous brown trout at sea. Journal of Fish Biology 59, 533-543.

Pemberton, R. (1976). Sea trout in North Argyll sea lochs. 2. Diet. Journal of Fish Biology 9 , 195-208.

Pinheiro, J., Bates, D., DebRoy, S., Sarkar, D. \& Team, R. C. (2017). nlme: Linear and Nonlinear Mixed Effects Models. R package version 3.1-130, https://CRAN.Rproject.org/package $=$ nlme.

Rikardsen, A. H., Amundsen, P. A., Knudsen, R. \& Sandring, S. (2006). Seasonal marine feeding and body condition of sea trout (Salmo trutta) at its northern distribution. ICES Journal of Marine Science 63, 466-475.

Rikardsen, A. H., Diserud, O. H., Elliott, J. M., Dempson, J. B., Sturlaugsson, J. \& Jensen, A. J. (2007). The marine temperature and depth preferences of Arctic charr and sea trout, as recorded by data storage tags. Fisheries Oceanography 16, 436-447. 
RStudio Team (2015). RStudio: integrated development for R. RStudio, Inc., Boston, MA URL http://www.rstudio.com.

Thorstad, E.B., Rikardsen, A.H., Alp, A. \& Økland, F. 2013. The use of electronic tags in fish research - an overview of fish telemetry methods. Turkish Journal of Fisheries and Aquatic Sciences 13, 881-896.

Thorstad, E. B., Todd, C. D., Uglem, I., Bjørn, P. A., Gargan, P. G., Vollset, K. W., Halttunen, E., Kålås, S., Berg, M. \& Finstad, B. (2015). Effects of salmon lice Lepeophtheirus salmonis on wild sea trout Salmo trutta-a literature review. Aquaculture Environment Interactions 7, 91-113.

Thorstad, E. B., Todd, C. D., Uglem, I., Bjørn, P. A., Gargan, P. G., Vollset, K. W., Halttunen, E., Kålås, S., Berg, M. \& Finstad, B. (2016). Marine life of the sea trout. Marine Biology 163, 47.

Wootten, R., Smith, J. W. \& Needham, E. A. (1982). Aspects of the biology of the parasitic copepods Lepeophtheirus salmonis and Caligus elongatus on farmed salmonids, and their treatment. Proceedings of the Royal Society of Edinburgh. Section B. Biological Sciences 81, 185-197.

Závorka, L., Slavík, O. \& Horký, P. (2014). Validation of scale-reading estimates of age and growth in a brown trout Salmo trutta population. Biologia 69, 691-695. 
Tables:

Table 1: Temperature and salinity measured by data loggers at $1 \mathrm{~m}$ depth in inner parts of Hemnfjord, inner parts of Snillfjord and in outer parts of the study area (Fig. 1) during May September 2013, November 2013 and February 2014* (*4 February - 1 March).

\begin{tabular}{lccccc}
\hline & \multicolumn{3}{c}{ Temperature $\left({ }^{\circ} \mathbf{C}\right)$} & \multicolumn{2}{c}{ Salinity } \\
\hline May - September 2013 & Average & SD & Range & Average & SD \\
Inner parts of Hemnfjord & 13.4 & \pm 2.9 & $4.8-18.3$ & 26 & \pm 7.4 \\
Inner parts of Snillfjord & 12.9 & \pm 3.0 & $5.3-17.9$ & 24 & \pm 4.7 \\
Outer areas & 12.6 & \pm 2.5 & $5.1-16.2$ & 21 & \pm 2.0 \\
& & & & & \\
November 2013 & Average & SD & Range & Average & SD \\
Inner parts of Hemnfjord & 9.3 & \pm 0.6 & $6.7-10.8$ & 31 & \pm 1.7 \\
Inner parts of Snillfjord & 8 & \pm 2.3 & $2.0-10.8$ & 16 & \pm 6.9 \\
Outer areas & 8.8 & \pm 0.8 & $6.1-10.2$ & 24 & \pm 0.8 \\
& & & & & \\
February 2014* & Average & SD & Range & Average & SD \\
Inner parts of Hemnfjord & 6.9 & \pm 0.3 & $5.8-7.7$ & 35 & \pm 0.3 \\
\hline
\end{tabular}


Table 2: Model selection for estimating the determinants of the swimming depth of S. trutta. during summer. The models estimate the relative contributions to the swimming depth from the parameters time of day (day vs. night, $D$ ), habitat $(H)$, month during summer $(M)$, body length $(L)$ and water temperature $(T)$. AIC is the score based on Akaike's information criterion.

\begin{tabular}{lcccr}
\hline Model & AIC & $\Delta$ AIC & AIC weights & d.f. \\
\hline$[D, H, M, L, T]$ & 1643565 & 0 & 0.998 & 11 \\
{$[D, H, M, T]$} & 1643577 & 12.31 & 0.002 & 10 \\
{$[D, H, M, L]$} & 1651227 & 7662.29 & 0 & 10 \\
{$[D, H, M]$} & 1651241 & 7676.01 & 0 & 9 \\
{[]} & 1981745 & 338180.32 & 0 & 3 \\
\hline
\end{tabular}


Table 3: Summary of intercept and fixed effects from mixed effect models on swimming depth during summer (log-transformed) and vertical movement activity (VMA).

\begin{tabular}{|c|c|c|c|c|c|}
\hline Model & Effect & Estimate (95\% C.I.) & $t$ & d.f. & $P$ \\
\hline \multirow[t]{11}{*}{ Swimming depth during summer } & (Intercept) & $0.53(0.41,0.65)$ & 8.91 & 825266 & $<0.001$ \\
\hline & Habitat: Estuary & $-0.73(-0.75,-0.71)$ & -68.58 & 825266 & $<0.001$ \\
\hline & Habitat: Near shore without cliffs & $-0,03(-0.05,-0.01)$ & -3.22 & 825266 & $<0.05$ \\
\hline & Habitat: Pelagic & $-0.44(-0.47,-0.41)$ & -29.49 & 825266 & $<0.001$ \\
\hline & Body length & $0.18(0.10,0.27)$ & 4.37 & 38 & $<0.001$ \\
\hline & Month: May & $-0.70(-0.71,-0.70)$ & -165.66 & 825266 & $<0.001$ \\
\hline & Month: June & $-0.50(-0.50,-0.50)$ & -182.7 & 825266 & $<0.001$ \\
\hline & Month: July & $-0.11(-0.11,-0.10)$ & -41.63 & 825266 & $<0.001$ \\
\hline & Month: September & $-0.24(-0.24,-0,23)$ & -90.97 & 825266 & $<0.001$ \\
\hline & Water temperature & $0.14(0.13,0.14)$ & 87.3 & 825266 & $<0.001$ \\
\hline & Time of day: Night & $-0.36(-0.37,-0.36)$ & -220.53 & 825266 & $<0.001$ \\
\hline \multirow[t]{6}{*}{ Vertical movement activity (VMA) } & (Intercept) & $0.72(0.52,0.92)$ & 7.08 & 5137 & $<0.001$ \\
\hline & Julian Day & $0.00(0.00,0.00)$ & 13.15 & 5137 & $<0.001$ \\
\hline & Habitat: Estuary & $-0.39(-0.58,-0.20)$ & -4.09 & 5137 & $<0.001$ \\
\hline & Habitat: Near shore without cliffs & $-0.04(-0.23,0.14)$ & -4.46 & 5137 & $>0.05$ \\
\hline & Habitat: Pelagic & $-0.13(-0.41,0.16)$ & -0.88 & 5137 & $>0.05$ \\
\hline & Time of day: Night & $-0.16(-0.18,-0.14)$ & -16.69 & 5137 & $<0.001$ \\
\hline
\end{tabular}


Table 4: Difference in mean swimming depth between day and night when recorded in various marine habitats (based on individual mean values) in summer (1 May-1 October 2013). Paired Mann-Whitney U-test $P$-values describe level of statistical significance between the swimming depths during day and night.

\begin{tabular}{lccccc}
\hline \multicolumn{1}{l}{ Habitat } & \multicolumn{5}{c}{ Mean swimming depth $(\mathrm{m})$} \\
& Day & Night & Difference & W & P-value \\
\hline Estuary & 1.0 & 0.7 & 0.3 & 399 & $<0.001$ \\
Near shore without steep cliffs & 2.1 & 1.3 & 0.8 & 805 & $<0.001$ \\
Near shore with steep cliffs & 2.7 & 1.7 & 1.0 & 45 & $<0.05$ \\
Pelagic & 1.3 & 0.8 & 0.5 & 257 & $<0.05$ \\
Total Marine & 1.9 & 1.2 & 0.7 & 794 & $<0.001$ \\
\hline
\end{tabular}


Table 5: Proportional distribution (\%) of the registrations at different depths (m) for tagged individuals $(n)$ when residing in different habitats during summer (1 May - 1 October 2013). Depths are given as meters from the surface.

\begin{tabular}{|c|c|c|c|c|c|}
\hline Depth $(\mathrm{m})$ & & $\begin{array}{l}\text { Estuarine habitat } \\
\qquad(n=29)\end{array}$ & $\begin{array}{l}\text { Near shore habitat } \\
\text { without steep cliffs } \\
\qquad(n=40)\end{array}$ & $\begin{array}{c}\text { Near shore } \\
\text { habitat with } \\
\text { steep cliffs } \\
(n=15)\end{array}$ & $\begin{array}{c}\text { Pelagic habitat } \\
\qquad(n=28)\end{array}$ \\
\hline \multirow[b]{2}{*}{$0-0.5$} & Mean & $8 \%$ & $10 \%$ & $7 \%$ & $19 \%$ \\
\hline & Range & $0-47 \%$ & $0-46 \%$ & $0-71 \%$ & $0-78 \%$ \\
\hline \multirow[b]{2}{*}{$0.5-1.5$} & Mean & $76 \%$ & $42 \%$ & $22 \%$ & $57 \%$ \\
\hline & Range & $41-96 \%$ & $1-70 \%$ & $0-62 \%$ & $13-100 \%$ \\
\hline \multirow[b]{2}{*}{$1.5-3.0$} & Mean & $14 \%$ & $25 \%$ & $42 \%$ & $14 \%$ \\
\hline & Range & $2-46 \%$ & $0-48 \%$ & $6-88 \%$ & $0-62 \%$ \\
\hline \multirow[b]{2}{*}{$3.0-5.0$} & Mean & $1 \%$ & $12 \%$ & $14 \%$ & $4 \%$ \\
\hline & Range & $0-13 \%$ & $0-52 \%$ & $0-50 \%$ & $0-28 \%$ \\
\hline \multirow{2}{*}{$5.0-10.0$} & Mean & $1 \%$ & $9 \%$ & $13 \%$ & $4 \%$ \\
\hline & Range & $0-20 \%$ & $0-87 \%$ & $0-78 \%$ & $0-33 \%$ \\
\hline \multirow{2}{*}{$>10$} & Mean & $0 \%$ & $1 \%$ & $1 \%$ & $1 \%$ \\
\hline & Range & $0-3 \%$ & $0-19 \%$ & $0-6 \%$ & $0-13 \%$ \\
\hline
\end{tabular}


Table 6: Vertical movement activity (VMA) of tagged fish when recorded in different habitats during day and night. Paired Mann-Whitney Utest statistics describe differences in VMA of fish during day and night.

\begin{tabular}{|c|c|c|c|c|c|c|c|c|c|}
\hline \multirow{3}{*}{ Habitat } & \multicolumn{4}{|c|}{ Time of day } & \multirow{2}{*}{\multicolumn{5}{|c|}{ Paired Mann-Whitney U-test }} \\
\hline & \multicolumn{2}{|c|}{ Day } & \multicolumn{2}{|c|}{ Night } & & & & & \\
\hline & Mean $(\mathrm{m})$ & Range (m) & Mean $(\mathrm{m})$ & Range(m) & Hypothesis $\left(\mathrm{H}_{0}\right)$ & $w$ & $n_{1}$ & $n_{2}$ & $P$-value \\
\hline Estuary & 0.4 & $0.2-1.3$ & 0.2 & $0.0-0.7$ & VMA day $\leq$ VMA night & 369 & 29 & 28 & $<0.001$ \\
\hline Near shore without steep cliffs & 0.8 & $0.3-1.8$ & 0.4 & $0.1-1.0$ & VMA day $\leq$ VMA night & 814 & 40 & 40 & $<0.001$ \\
\hline Near shore with steep cliffs & 0.9 & $0.4-1.3$ & 0.4 & $02 .-0.6$ & VMA day $\leq$ VMA night & 45 & 15 & 9 & $<0.001$ \\
\hline Pelagic & 0.5 & $0.0-1.6$ & 0.2 & $0.0-0.6$ & VMA day $\leq$ VMA night & 186 & 27 & 21 & $<0.001$ \\
\hline
\end{tabular}


Figure captions:

Figure 1: Locations of automatic acoustic receivers in different habitats ( $\nabla$ estuary; near shore area without steep cliffs; $\Delta$ near shore area with steep cliffs; • pelagic area) and temperature and salinity data loggers (T/S) in the study area.

Figure 2: Mean daily water temperatures $\left({ }^{\circ} \mathrm{C}\right)$ at $1 \mathrm{~m}$ depth in the inner part of Hemnfjord (grey line), inner part of Snillfjord (grey, stippled line) and outer part of the study area (black line) in the period $01.05-01.10 .2013$.

Figure 3: Temperature $\left({ }^{\circ} \mathrm{C}\right)$ and salinity at $0-15$ meters depth in central fjord areas of Hemnand Snillfjord on 18.04.2013 (black lines) and 22.08.2013 (grey lines).

Figure 4: Monthly average individual swimming depth in estuarine habitat, near shore habitat without steep cliffs, near shore habitat with steep cliffs and pelagic habitat during summer (01.05 - 01.10.2013). The box-and-whisker plots show median values (black lines), the interquartile ranges (boxes) and the 5th and 95th percentiles (whiskers). Circles indicate outliners.

Figure 5: Individual mean swimming depth in different habitats during day (white) and night (grey) during summer (01.05 - 01.10.2013). The box-and-whisker plots show median values (black lines), the interquartile ranges (boxes) and the 5th and 95th percentiles (whiskers). Circles indicate outliners. 
Figure 1:

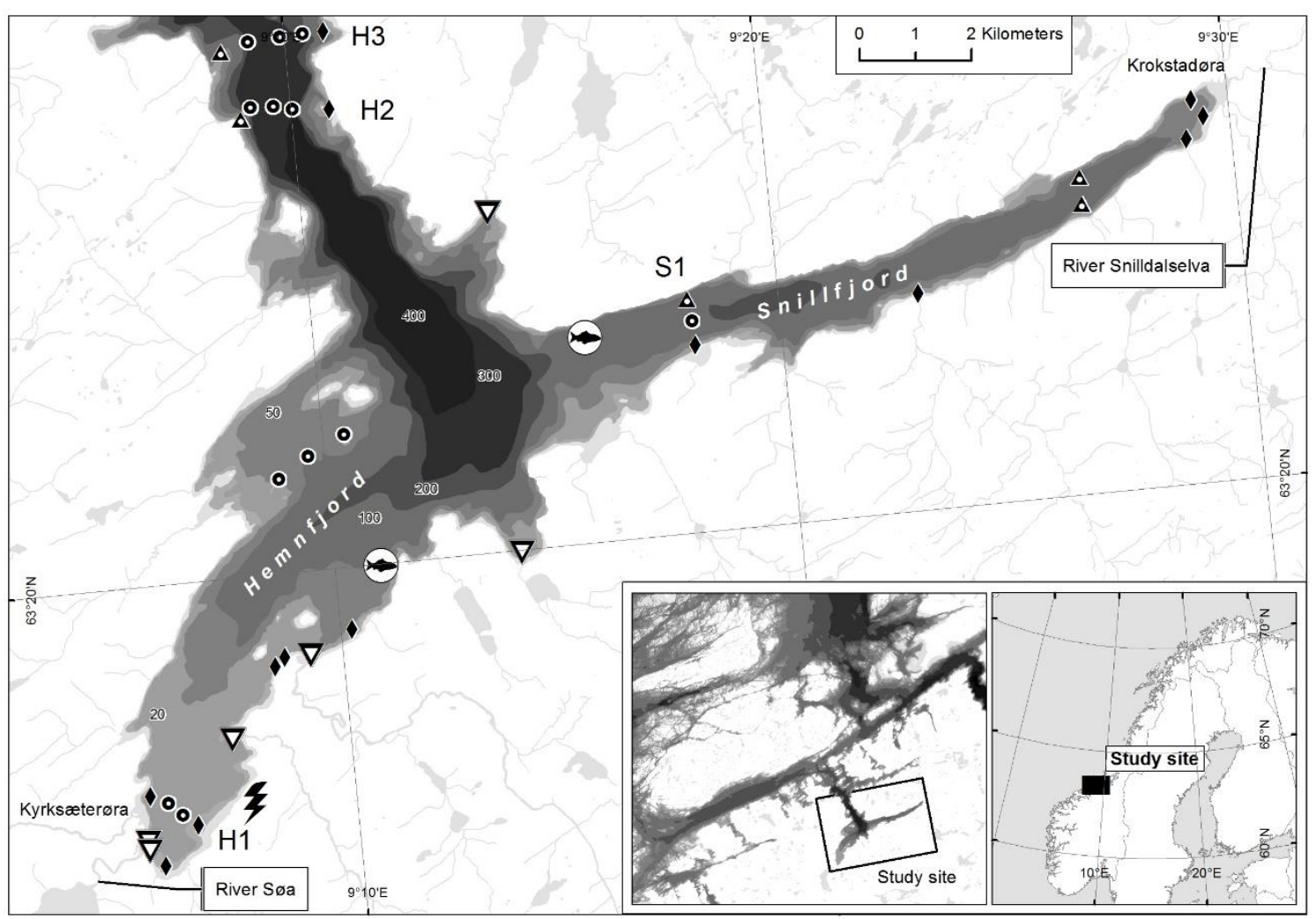


Figure 2:

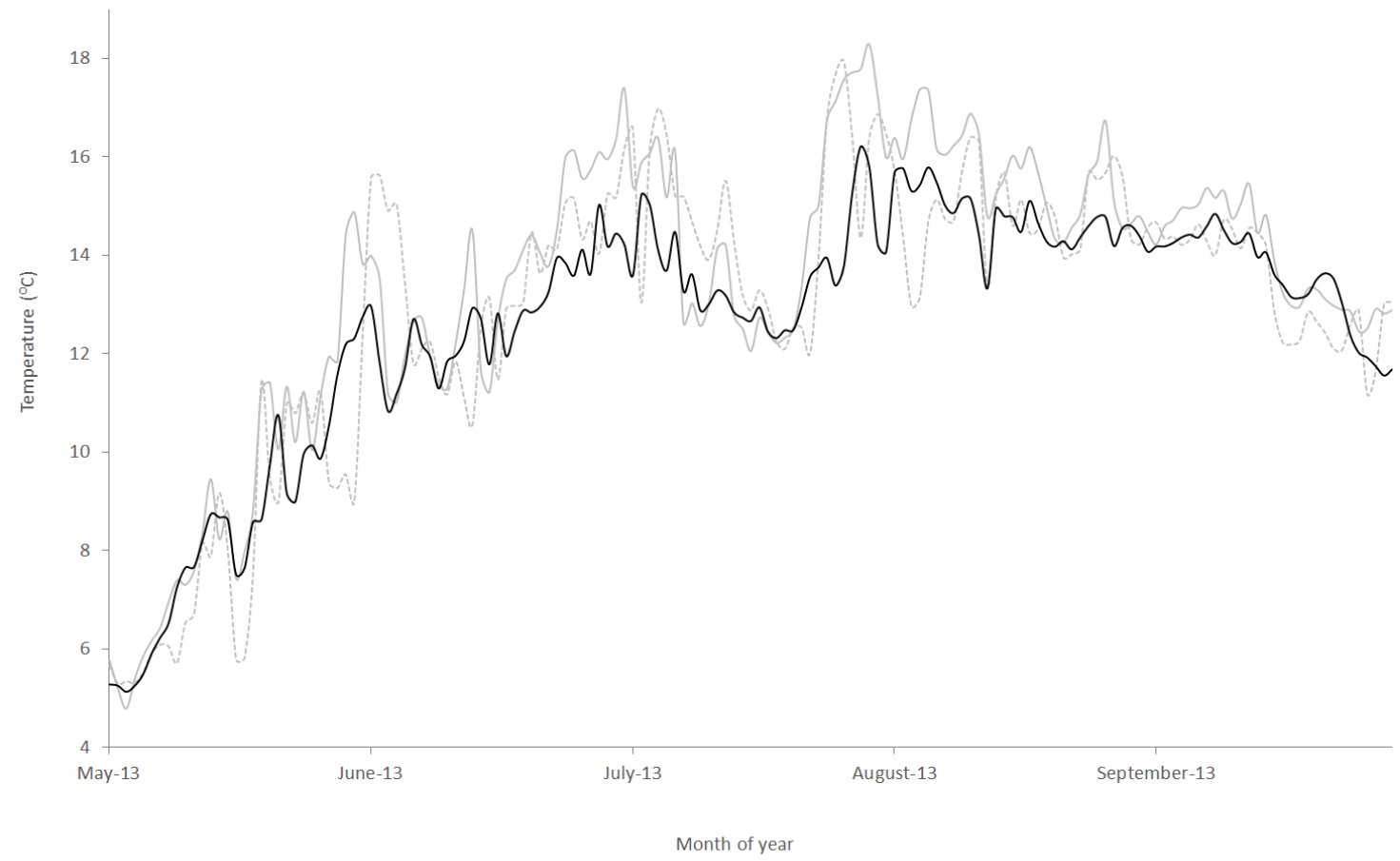


Figure 3:
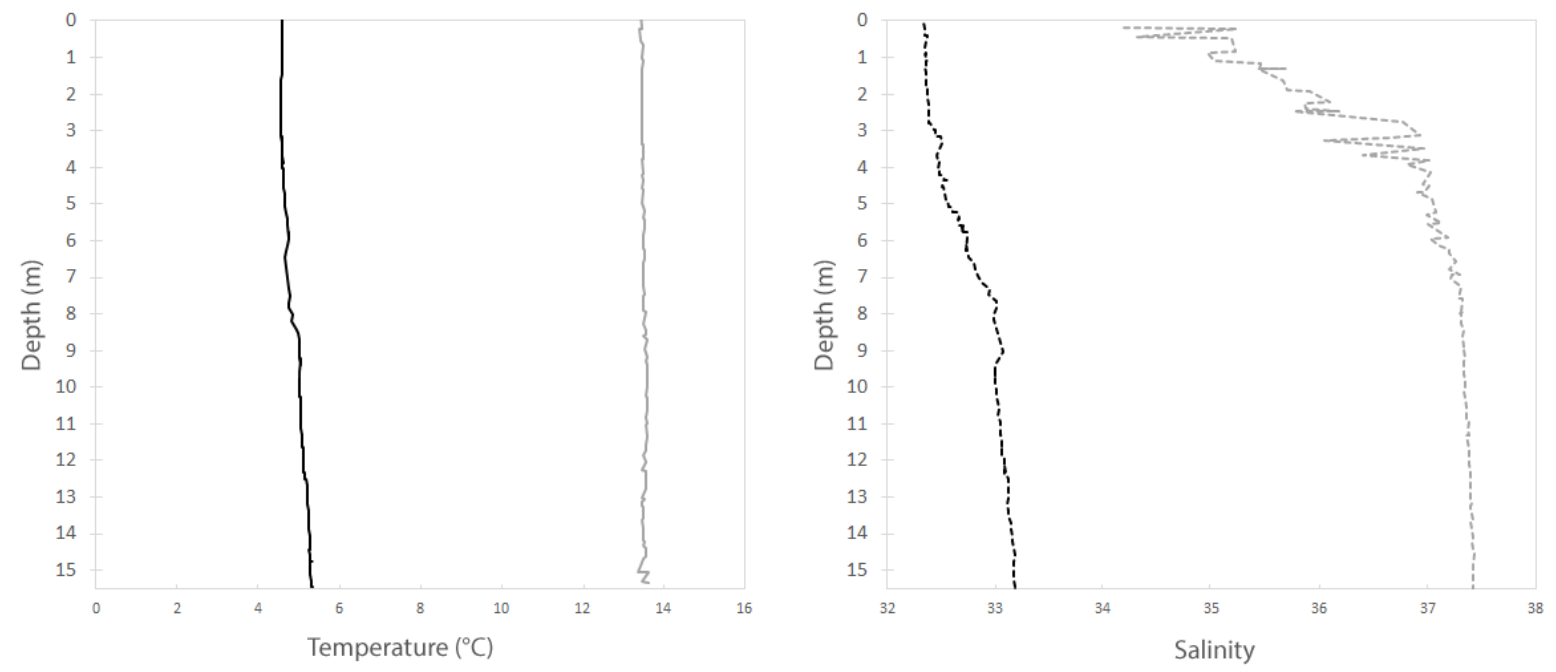
Figure 4:

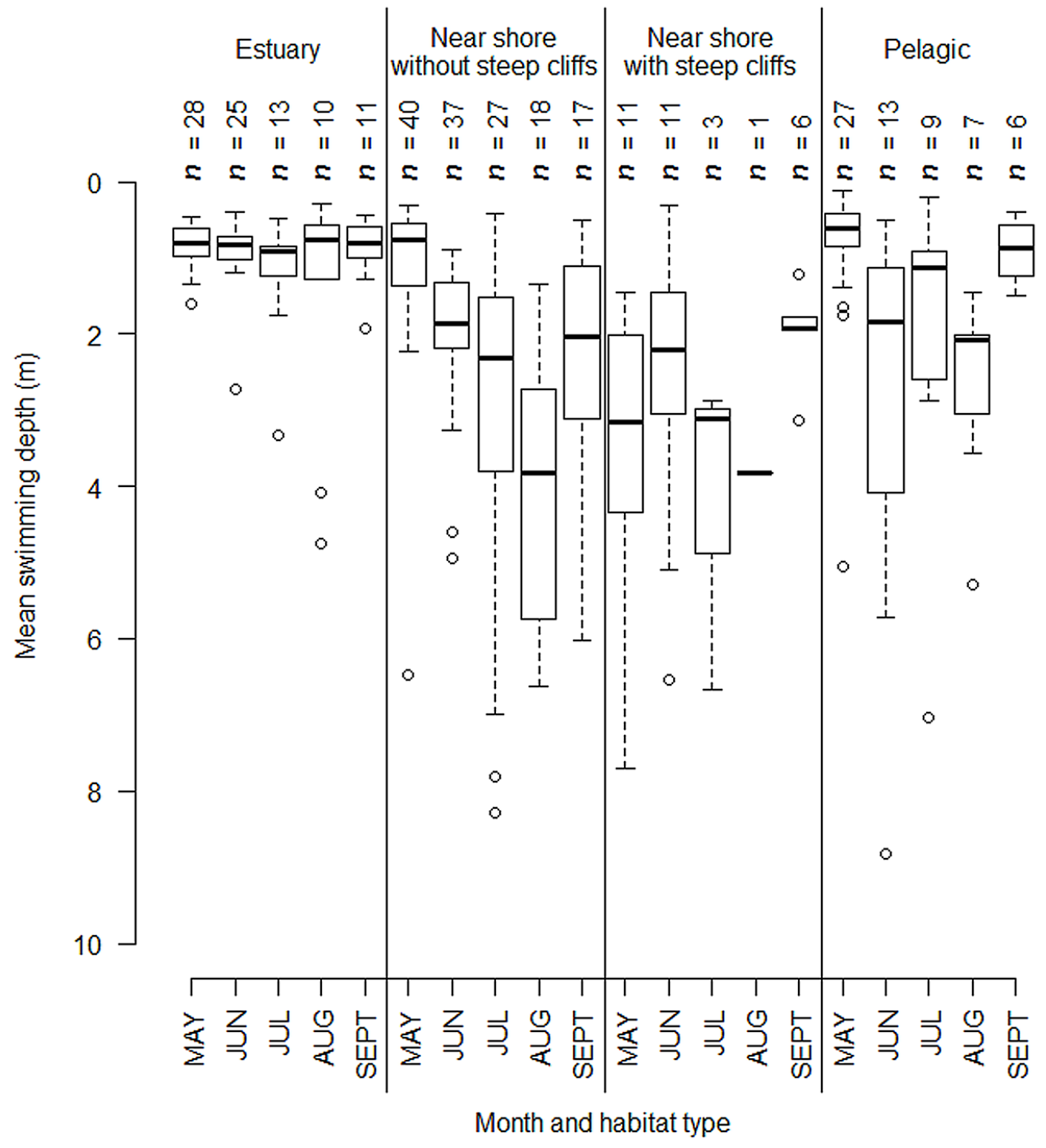


Figure 5:

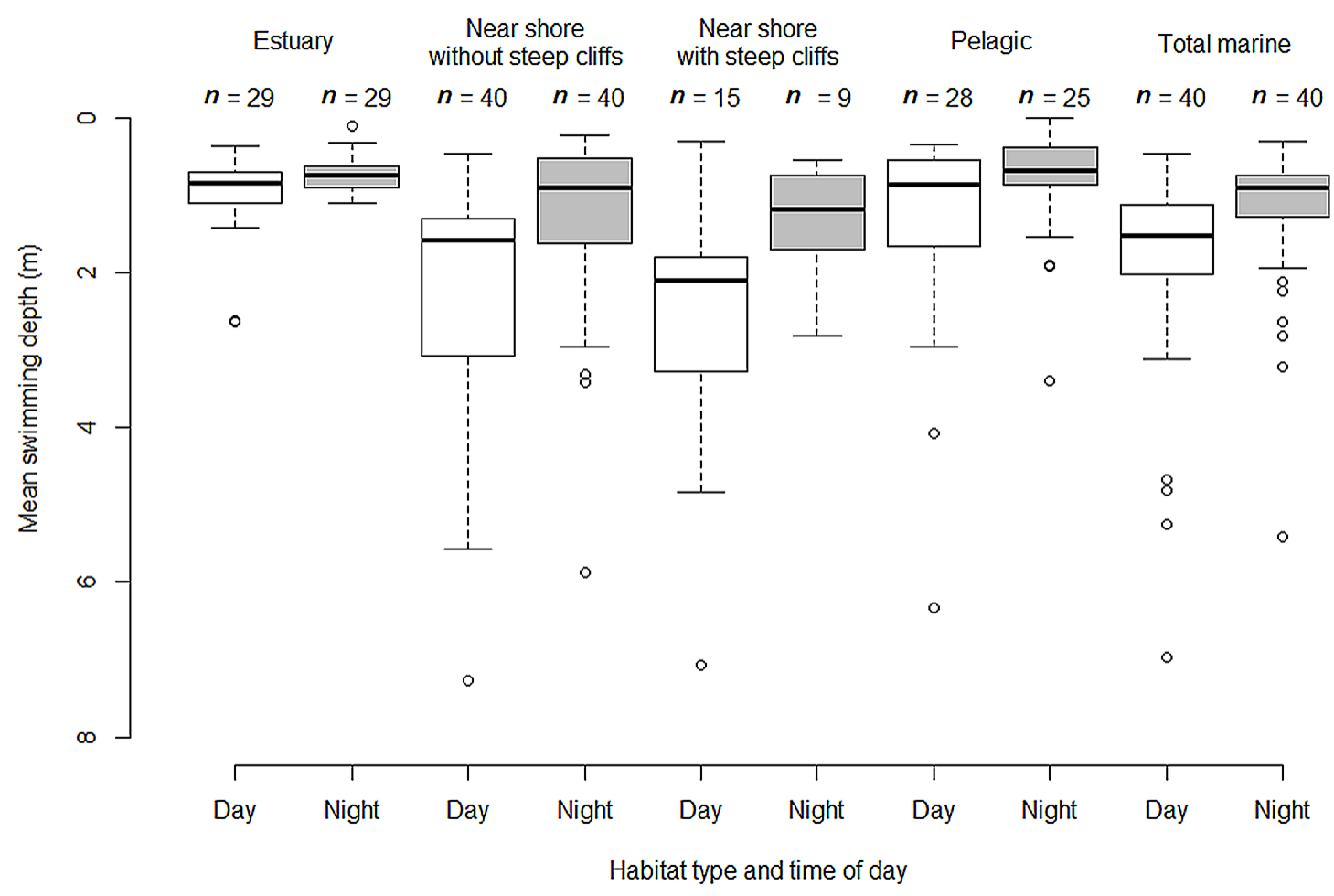

